African J. Biol. Sci., 15 (1): 101-115 (2019)

ISSN 1687-4870

www.aasd.byethost13.com

e- ISSN 2314-5501 (online)

e.mail: aasdjournal@yahoo.com

\title{
Control of the glassy clover snails Monacha cartusiana using Zingiber officinale extract as an ecofriendly molluscicide
}

\author{
Mahmoud Abd El-Atti ${ }^{1 *}$, Elsheakh A. A. ${ }^{2}$, Khalil A.M. ${ }^{1}$ and Wesam S. Elgohary ${ }^{2}$ \\ 1- Zoology Department, Faculty of Science, Zagazig University, Zagazig. Egypt \\ 2- Plant Protection Research Institute, Agr. Res. Center. Doki, Giza, Egypt \\ *Corresponding author email: mahmoudatti1@yahoo.com
}

\begin{abstract}
High population densities of Monacha cartusiana were observed to cause perdition of various economic crops at Sharkia Governorate. The present study was carried out control this harmful pest using ethanolic Ginger extract as a natural and environmentally safe molluscicide.Toxicological tests revealed that low concentration $(20 \%)$ of ethanolic Ginger extract caused $10 \%$ mortalityof cloversnails after one day of exposure and $66.7 \%$ mortalityafter 28 days. The highest mortality percentage $(90 \%)$ was recorded after 28 days of treatment with $40 \%$ Ginger extract. Biochemical investigations showed that $\mathrm{LC}_{25}(7.04 \%)$ Ginger extract elevated ALT, AST, $\alpha \& \beta$ esterases andphenoloxidase levels of treated snails compared to control.Histological inspections of the digestive gland and ovotestis of snails exposed to $\mathrm{LC}_{25}$ Ginger extract revealed that the digestive tubules showedvarious tubularanomalies, inflammatory hemocytes infiltration, excessive luminal secretionsand appearanceof necrotic areas. Acini of ovotestis weredeformedand comprised misshapen eggs and distorted sperms.TEM investigations showed cellular malformations in the digestive gland of treated snails including; severely disrupted microvilli, ruptured cell membranes, fractured RER and mitochondrial pyknosis.
\end{abstract}

Key words: Ecofreindly- Antioxidant Enzymes- Ginger extract-Histopathology- Monacha cartusiana-TEM.

\section{INTRODUCTION}

Land snails are considered as serious agricultural pests Egypt. They are herbivorous animals that devour mellow parts of vegetables, fruit trees and ornamental plants (Godan, 1983) and ruin mushy leaves, fruits, seeds and tubers (ElOkda, 1984). Undesirable smell and savor caused by mucous secretions left on plants during their movements, averts human and other animals from feedingon these contaminated plants (El-Deeb et al., 1999). The glassy clover snails (Monach cartusiana) were recorded extensively at vast geographic areas at the Mediterranean regions and Southeastern Europe (Pieńkowska, 2018: Pieńkowska et al.,
2019). High population densities were discoveredinfesting various economic crops at Sharkia Governorate, Egypt (Lokma, 2013). M. cartusiana reported to act also as an intermediate host for sheep lungworm and lancet liver fluke (Godan, 1983). Chemical control applications still the most commonly used for controlling land snailsalthough; they extensively prejudice non-target organisms including man (Gabr et al., 2006). The high costs and resistance exerted against synthetic pesticides encourage the usage of naturally derived pest control strategies (Massoud and Habib 2003). Recently, several countries enhanced the use of plant extracts in pest control due to their low mammalian toxicity, low costs 
Mahmoud Abd El-Atti et al.

and fast biodegradability (Singh et al., 2000). Ginger extracts possess antiinflammatory, analgesic, antioxidants and antimicrobial activities (Sharma et al., 2013; Nikoli et al., 2014; Amri and TouilBoukoffa, 2016). Few studies have been carried out on the molluscicidal activities of Ginger (Ahmad et al., 2013; and Edwin and Jacob 2017). Physiological and histopathological investigations give excellent indication about the hazards occurs within the organism because of exposure to toxicants. The present study aimed to control the glassy clover snail Monacha cartusiana using Ginger extract as a natural and alternative solution instead of using harmful chemical molluscicides.

\section{MATERIALS AND METHODS}

\section{Snails collection and acclimation}

Adult snails of $M$. cartusiana were collected from clover fields at Malames village, Meniet El-kamh district, Sharkia Governorate during spring 2018. Snailswere transferred to the laboratory and kept in glass cages $(50 \times 30 \times 30 \mathrm{~cm})$ contained moist soil and fed daily with fresh Lettuce for two weeks.

\section{Ginger extracts preparation}

Rhizomes of Ginger were purchased from the InternationalCompany (CairoEgypt). Rhizomeswere ground intoa fine powder using a pestle and mortar. The powder (30 g) was soaked in ethanol (600 $\mathrm{ml}$ ) in a Sechelt apparatus for twodays. Ethanol was evaporated under reducedpressure until brown extract was obtained (Bakry et al., 2013). Poisonous baits were formulated by mixing ethanolic Ginger extract with five grams of sugarcane syrup, completed with wheat bran to 100 grams and moisten with small amounts of water.

\section{Experimental design}

Clover snails were divided randomly into three main groups; the first group used for toxicological studies was subdivided into five sub groups and treated with different concentrations of Ginger extract for 28 days. Four replicates were applied for each subgroup.The second groupfed with baits containing $\mathrm{LC}_{25}$ of ginger extract for 14 days andused for biochemical, histopathological and ultrastructural investigations. The third group left as control group.

\section{Biochemical measurements:}

Digestive glands were dissected out from both control and treated snailsthen homogenized in distilled water using a Teflon homogenizer. The homogenates were centrifuged at 8000 r.p.m. for 15 minutes at $5^{\circ} \mathrm{C}$ inrefrigeratedcentrifuge. Deposits were discarded and supernatants were kept in a deep freezer untiluse. Activities of AST and ALT enzymes were determined according to the procedure of Reitman and Frankle (1957). Alpha and Beta esterases assayed according to Van Asperen, (1962). Phenoloxidase activitymeasured using the method of Ishaaya (1971).All biochemical measurements were carried out in Plant Protection Research Institute, Agriculture Research Centre, Giza, Egypt.

\section{Histopathological studies}

For light microscopy, digestive glands of both control as well as treated with $\mathrm{LC}_{25}$ Ginger extract for 14 days were dissected out and fixed in Bouin's fluid. Specimens dehydrated in a graded series ofethanol, cleared in Xylene for 20 minutes, impregnated in paraffin wax (three changes) at $60^{\circ} \mathrm{C}$ for 2 hours and embedded in paraffin wax. Sections (4-5 $\mu \mathrm{m}$ thick) were cut by microtome, mounted on glass slides andstained with hematoxylin and eosin.

\section{Ultrastructural studies}

Dissected digestive glands of both control and Ginger treated snails were fixed in $2.5 \%$ glutaraldehyde in $0.05 \mathrm{M}$ cocodylate 


\section{Control of the glassy clover snails Monacha cartusiana using Zingiber officinale extract as an ecofriendly molluscicide}

buffer containing 0.15 sucrose at $\mathrm{pH} 7$ for two hours. Specimens were fixed in $1 \%$ Osmium tetroxide at $4 \mathrm{oC}$ for an hour, dehydrated in an ascending series of ethanol and embedded in Araldite f Epon. Blocks were cut with diamond ultramicrotome knifes. Semithin sections stained with $1 \%$ Toluidine blue. Ultra-thin sections stained with aqueous Urinyl acetate and Lead citrate and examined under JEOL 100 CX TEM at the Electron Microscopy Unit, Faculty of Agriculture, El-Mansoura University, Egypt.

\section{Statistical analysis:}

Values of toxicological and biochemical studies were expressed as a mean \pm SE. The obtained data were analyzed statistically for the significance of differences using student's t-test (Goldstein, 1964).

\section{RESULTS}

\section{Toxicity tests}

Figure (1) showed that snail mortalities increased with increasing of both Ginger extract concentrations and exposuretime. At the first day of exposure, all treatments caused low mortalities. Ethanolic extract of Ginger (20\%) causes $10,50,56.6,66$ and $66.7 \%$ mortalitiesafter $1,7,14,21$ and 28 days of treatment respectively.Exposure to $30 \%$ Ginger extract caused 6.6, 36.7, 70, 76.6 and 83.3\% for the same days of exposurerespectively.Finally, $40 \%$ Ginger extract resulted in 10, 46.6, 76.6, 83.3 and $90 \%$ respectively, at the same time intervals. The highest percentage of mortalities (90\%) occurred after treatment with $40 \%$ Ginger extract for 28 days (Fig. 1).

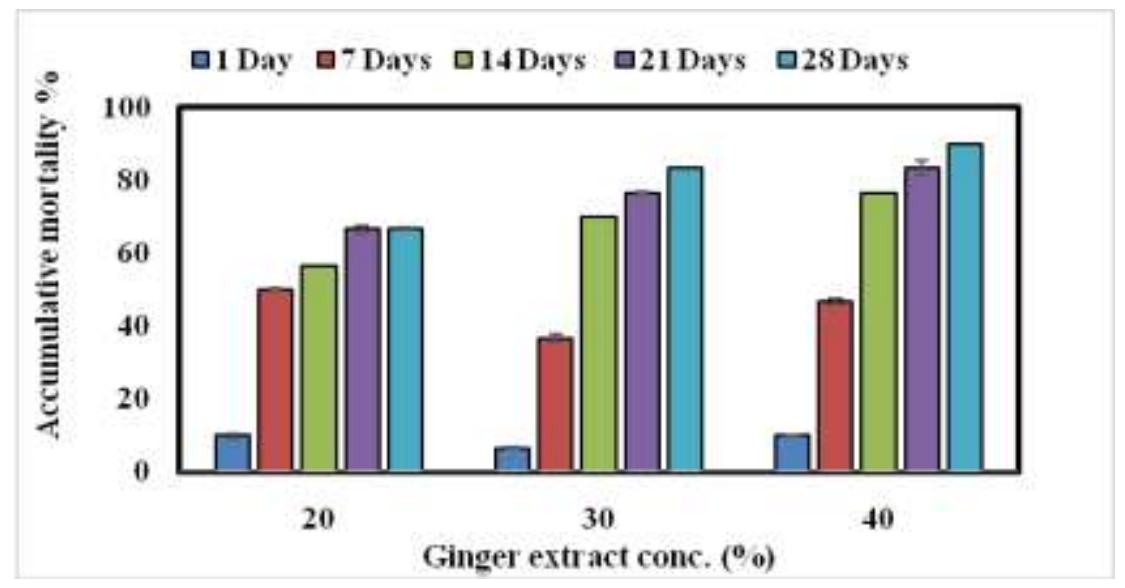

Fig.(1): Mortality percentages of $M$. cartusiana exposed to different concentrations of Ginger extract for 28 days.

\section{Biochemical measurements}

\subsection{Activities of ALT and AST}

Levels of AST were significantly elevated $(\mathrm{P}<0.05)$ after exposure to $\mathrm{LC}_{25}$ $(7.04 \%)$ of $Z$. officinale extract and the highest level was recorded after two weeks of exposure compared to control. Activities of ALT were significantly increased(P < 0.05 ) after the first day of treatment, while their levels slightly decreased with increasing time of exposure, although levels were much higher than control (Fig. 2).

\subsection{Activities of $\alpha$ and $\beta$-esterases}

$\mathrm{LC}_{25}$ of $Z$. officinale extract caused a highly significant increase $(\mathrm{P}<0.05)$ of $\alpha$ and $\beta$-esterases activities after the first day of exposure. Values of both enzymes were 
Mahmoud Abd El-Atti et al.

decreased insignificantly $(\mathrm{P}>0.05)$ after the $7^{\text {th }}$ and $14^{\text {th }}$ day of treatment (Fig. 2).

\subsection{Activity of Phenoloxidase}

Highly significant increase in the activity of Phenoloxidase was detected following the first day of treatment. Phenoloxidase levels decreased insignificantly $(\mathrm{P}>0.05)$ after one week of treatment. The lowest level of phenoloxidase was achieved after two weeks of exposure to Ginger extract (Fig. 2).

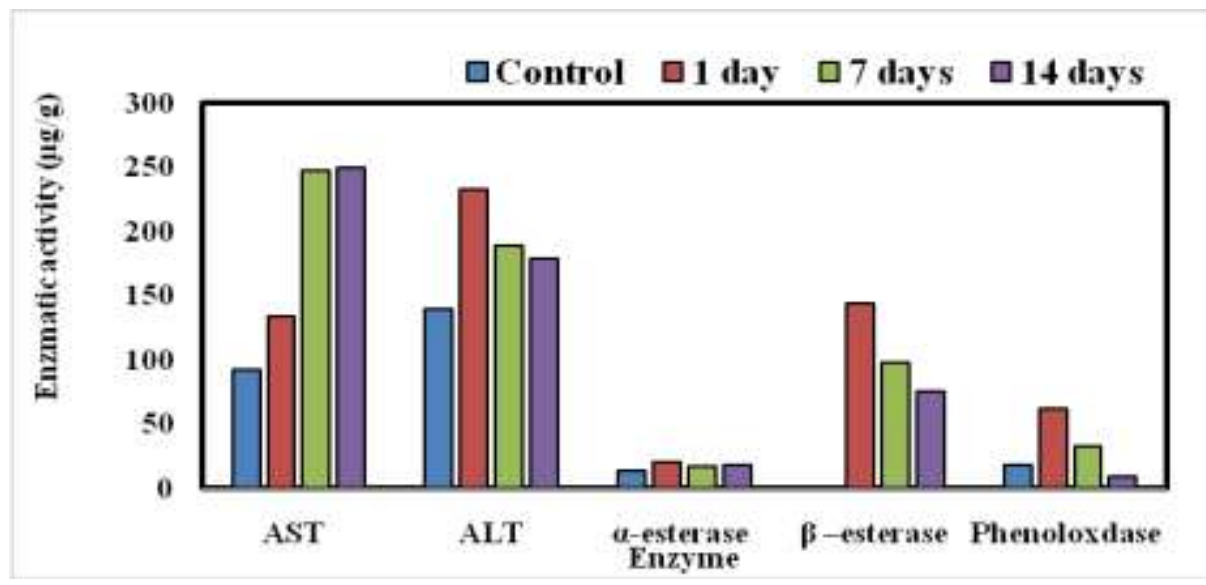

Fig. (2): Enzymatic activities of $M$. cartusiana treated with $\mathrm{LC}_{25}$ Ginger extract for 14 days.

\section{Microscopical Examination}

3.1. Histological studies on control digestive and hermaphrodite glands

The digestive gland of control $M$. cartusianacomprises mainly manynumerous blind digestive tubules separated by intertubular connective tissue containing hemolymphatic vessels and disparate hemocytes. Each tubule encircled with circular muscle layer (Plate I, Fig. a). Three different cell types constitute the epithelial lining of digestive tubules: digestive, excretory and calcium cells (Figs. b- d).

Digestive cells: Columnar cells, possessed many vacuolesaccommodating yellowish brown granules and basally located rounded or oval nuclei.
Excretory cells: Rounded cells incorporate large dark brown excretory granule and small basally locatednuclei.

Calcium cells: Occur singly or in groups, pyramidal-shape, stacked with rounded calcium spherules (appeared as light bodies) and have centrally located globular nuclei.

On the other hand, the hermaphrodite gland (ovotestis) is embedded in the digestive gland and consists of many ovoidacinieach is bounded by interacinar connective tissue containing interstitial cells. Each acinus isborderedby germinal epithelial layerand many Sertoli cells in between. Their lumens embrace developmental stages of spermatogenesis and oogenesis (Figs. e \&f). 


\section{Control of the glassy clover snails Monacha cartusiana using Zingiber officinale extract as an ecofriendly molluscicide}

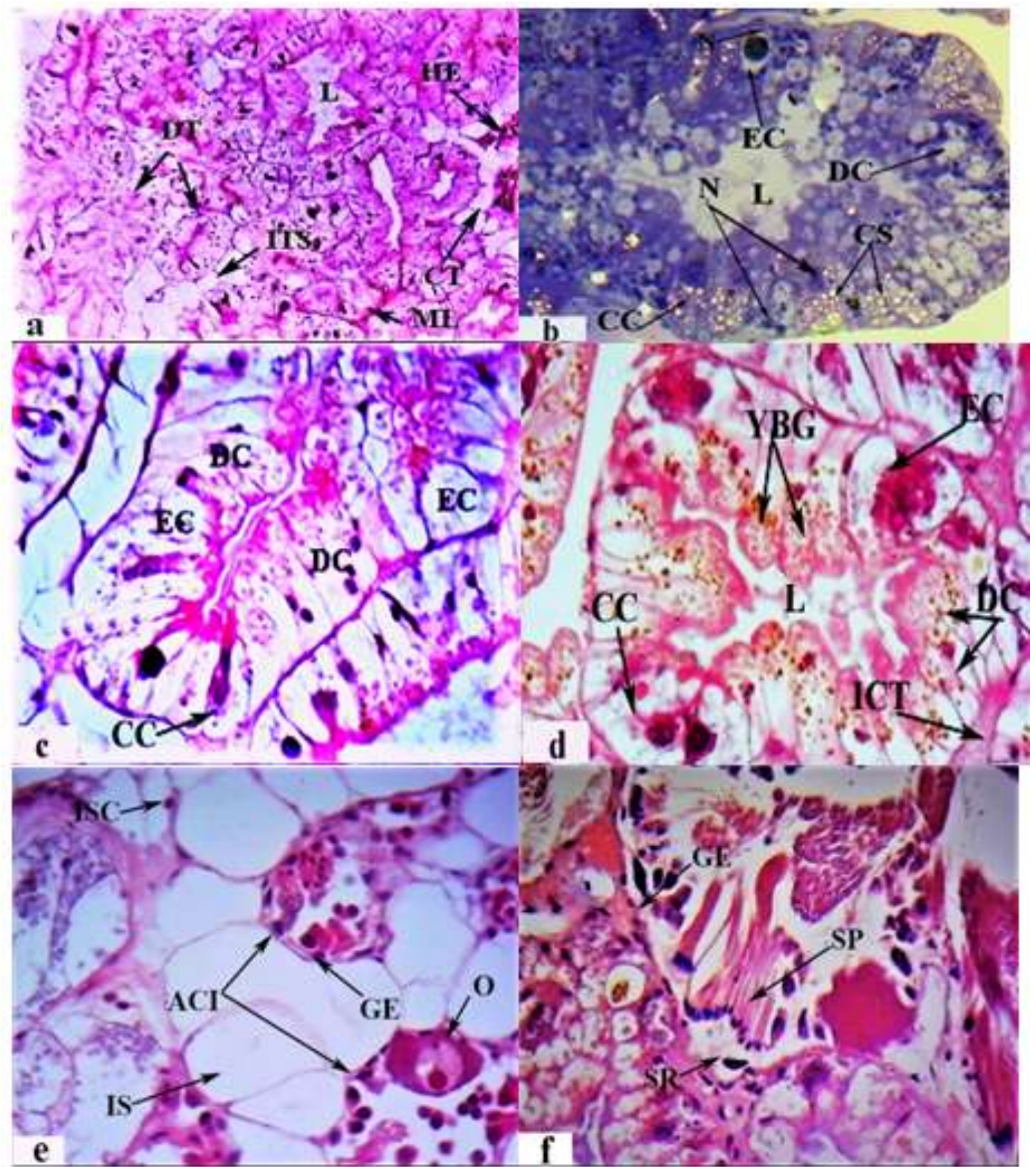

Plate I. Photomicrographs showing sections of the digestive and hermaphrodite glands of control $M$. cartusiana. (a):T.S. of untreated digestive gland showing the normal histological architectureof digestive tubules (X100). (b): Semi thin section showing different types of cells forming digestive tubule and calcium spherules of calcium cells (X400). (c \& d): Sections of the digestive tubules showing calcium cell at the corners, yellowish brown granules of digestive cells and large excretory dark granule of excretory cells (X400). (e \& F): Cross sections showing ovotestis acini of control $M$. cartusiana containing different developmental stages of oocytes and sperms (X400). ACI: Acini of the ovotestis; CC: Calcium cell; DC: Digestive cell; DT: Digestive tubules; EC: Excretory cell; GE: Germinal epithelium; HE: Hemocytes; ICT: Intertubular connective tissue; IS: Interacinar space; ISC: Interstitial cell; L: Lumen; ML: Muscle layer; PO: Primary oocyte; SO: Secondary oocyte; Sd: Spermatids; SP: Sperms; SR: Sertoli cell; YBG: Yellowish brown granules. 
Mahmoud Abd El-Atti et al.

\subsection{Ultrastructural studies of control digestive gland}

Transmission electron microscopic studies revealed that the hepatic ducts of M.cartusiana digestive glandarelined with a ciliated columnar epithelium resting on a thin basement membrane andsupported by connective tissue layer and circular muscle bundles. These cells have oval nucleiwith prominent nucleolus and surrounded with thin layer of rough endoplasmic reticulum. Their cytoplasm is homogenous and contains many pinocytotic vesicles, whichwere noted also in the underlying connective tissue layer. Mitochondria are oval and more concentrated at the apex of these cells (plate II, Figs. a\&b).Electron micrographs confirmed the presence of three main cell types constituting the epithelial lining of the tubules which are differentiated into; digestive, excretory and calcium cells.

Digestive cells: Their outer borders provided with well-developed microvilli projecting towards the lumenand havebasally ovalnuclei. Mitochondria and rough endoplasmic reticulum are scattered throughout cytoplasm. The cytoplasm contains alsomany electron- dense lysosomalgranules showing different states of activities. Adjacent digestive cells are interconnected by inter inter-cellular junctions (Fig.c).

Calcium cells: Pyramidal cells have numerous apical microvilliand rounded nuclei. Their cytoplasm possesses many electron- lighted calcium spherules, electron dense granules and oval mitochondria which are more concentrated at the apex (Fig. d).

Excretory cells: Rounded cells contain massive microvilli in their free border. The nucleus is rounded, basally located and surrounded bydense layer of rough endoplasmic reticulum and numerous oval mitochondria. The cytoplasm filled with dark osmiophilic excretory granules. A smaller excretory cell (regenerative) was noted beside the mature one that has a large globular nucleus containing an eccentric nucleolus. Its cytoplasm is condensed, containing few mitochondria and devoid of excretory granules (Figs. e\& f).

\subsubsection{Treated digestive gland}

Light microscopic examinations of the digestive gland treated with $\mathrm{LC}_{25}$ ofGinger extract revealed various tubular deteriorations, inflammatory hemocytic infiltrations, tissue exudates and excessive luminal secretions. The epithelial lining undergoes vacuolization, extensive cell lysis and necrotic areas. The basement membranes and muscular layers surrounding tubules were lacerated. The digestive cells have accumulations of large numbers of darkly stained granules and pyknotic nuclei. Excretory cells showed decreased amount of dark brown granules. Calcium cells were disrupted and have few number of calcium spherules (Plate III, Figs. a-d). 


\section{Control of the glassy clover snails Monacha cartusiana using Zingiber officinale extract as an ecofriendly molluscicide}

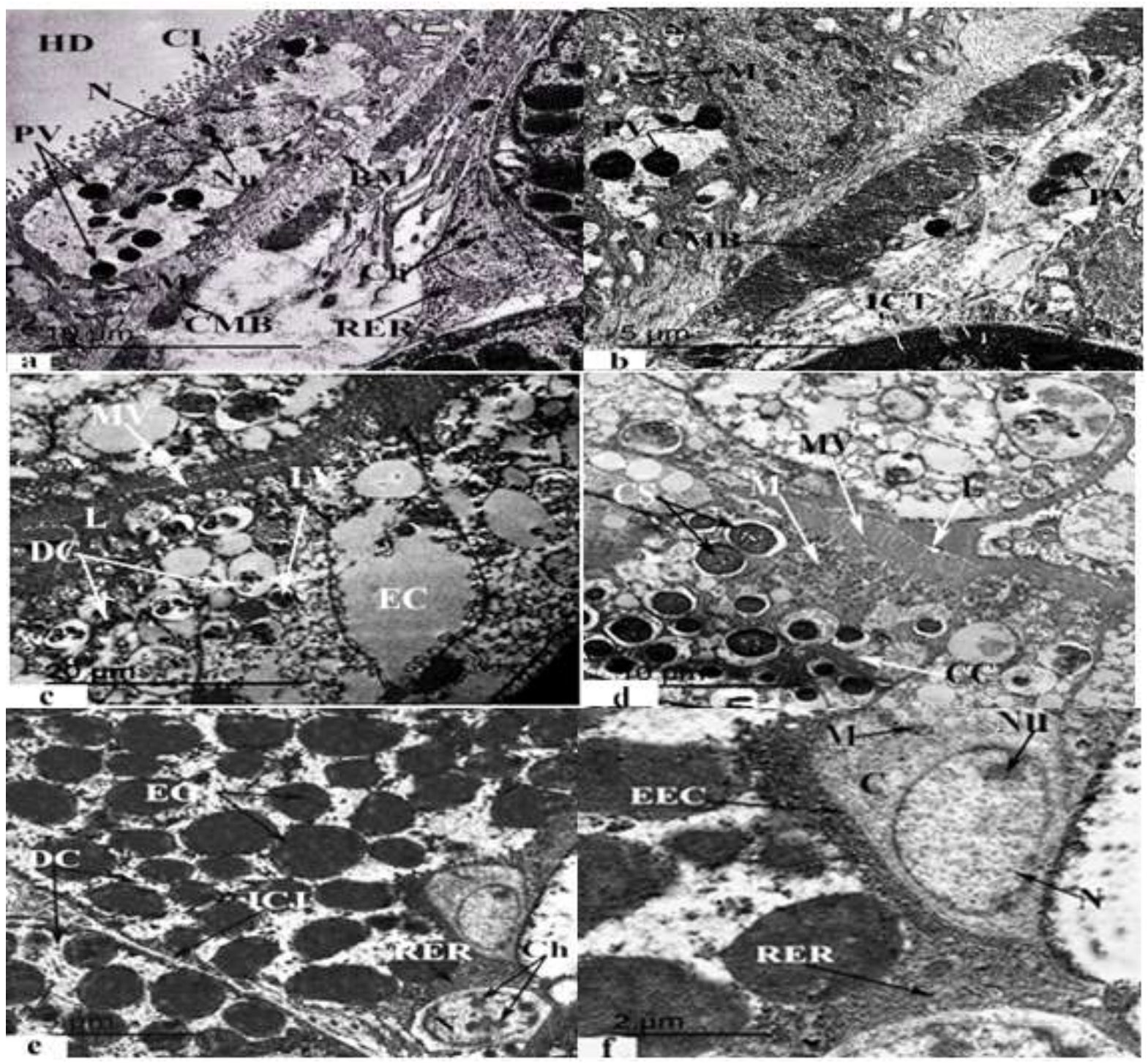

Plate II. Electron micrographs showing normal cellular structures of the digestive gland of $M$. cartusiana.(a): Ciliated columnar cells lining the hepatic duct (X13600). (b): Connective tissue layer and circular muscle bumbles surrounding digestive tubules (X17000). (c): Cellular lining of digestive tubule showing group of digestive cells (X 6800). (d): Calcium cells containing characteristic calcium spherules (X6800). (e): The basal region of excretory cell and secretory granules (X17000). (f): Small regenerative excretory cell (X17000). BM: Basement membrane; C: Cytoplasm; CC: Calcium cells; CH: Chromatin material ; CS: Calcium spherules; CI: Ciliated columnar epithelium; CMB: Circular muscle bundles; CT: connective tissue; DC: Digestive cell ; DV: Digestive vesicles; EC: Excretory cells; EG: Excretory granules; EEC: Regenerative (Embryonic) excretory cell; HD: Hepatic duct; ICJ: Inter cellular junctions; ICT: Intertubular connective tissue; L: Lumen; LV: Lysosomal vesicles; M: Mitochondria; MV: Microvilli; N: Nucleus; NU: Nucleolus; PV: Pinocytotic vesicles; RER: Rough endoplasmic reticulum. 


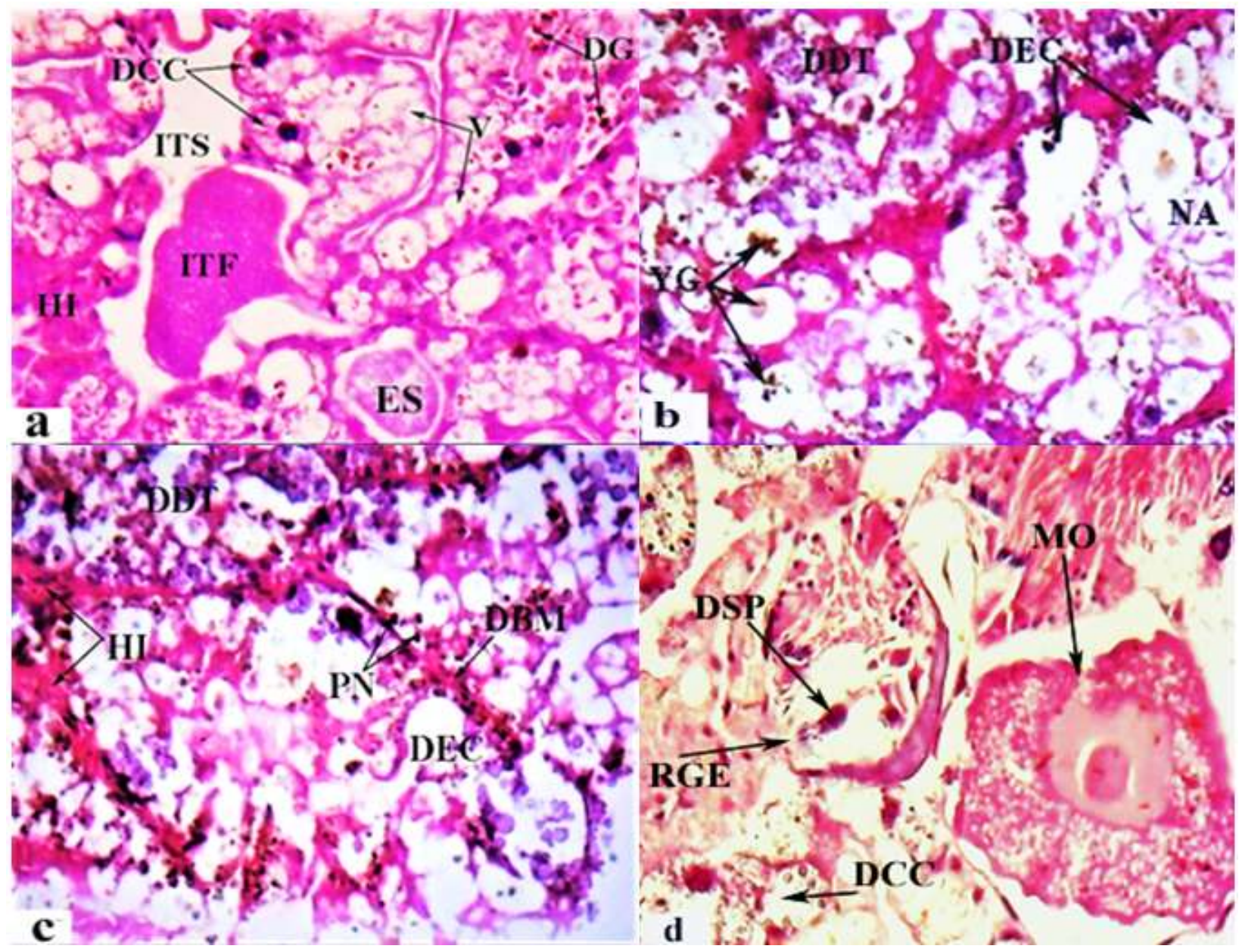

Plate III. (a- c): Photomicrograph showing cross sections through the digestive gland of $M$. cartusiana treated with $\mathrm{LC}_{25}$ of ethanolic Ginger extract for 2 weeks(X 400). (d): T. S. of treated ovotestis showing deformed oocyte and sperms(X 400). CL: Cell lysis; CS: Calcium spherules; DBM: Degenerated basement membrane; DCC: Deformed calcium cells; DEC: Deformed excretory cells; DDT: Deformed digestive tubules; DG: Dark granules; DSP: Deformed spermatozoa; EC: Excretory cell; ES: Excessive secretions; ITF: Intertubular filtrate; HA: Hermaphroditic acinus; HI: Hemocytic infiltration; N: Nucleus; NA: Necrotic area; PN: Pyknotic nuclei; S: Secretions; YG: Yellowish brown granules.

\subsection{Ultrastructural abnormalities}

Electron micrographs of the digestive gland of $M$. cartusiana treated with $\mathrm{LC}_{25}$ Ginger illustrated many ultrastructural abnormalities as severely ruptured microvilli of digestive and calcium cells.Excessive cloudy luminal secretions were noted. Cell membranes of various cells were lacerated. The cytoplasm was highly vacuolated inclosing denselyosmiophilic granules and lysosomal vesiclescomprising cellular debris. RER of excretory and calcium cells were ruptured in the form of disorganized tubules. .Mitochondria showed condensation of their matrix (mitochondrial pyknosis) andsprinkled cristaeand the nuclei became pyknotic. Intercellular junctions of adjacent cells were deformed (Plate IV, Figs. a- d). 
African J. Biol. Sci., 15 (1): 101-115 (2019)

ISSN 1687-4870

www.aasd.byethost13.com

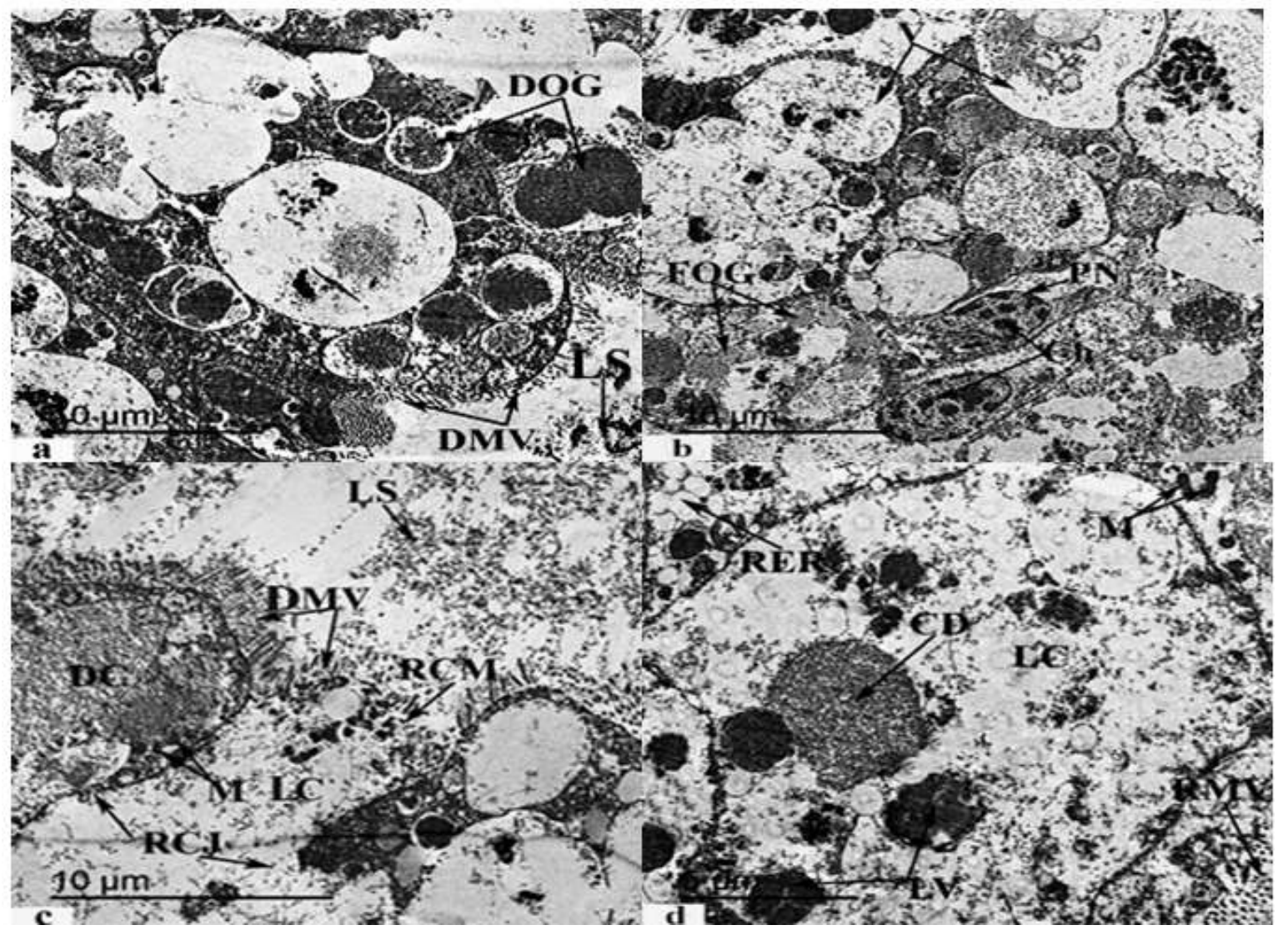

Plate IV. (a) Electron micrographs showing ultrastructural alterations in the digestive gland of $M$. cartusiana treated with $\mathrm{LC}_{25}$ Ginger ethanolic extract. (a):Apical portion of digestive cellshowing disrupted microvilli(X 10200). (b): Basal region of excretory cellshowing nuclear pyknosis and vacuolization (X 13600). (c): Digestive cell with distorted brush boarder and pyknotic mitochondria $(X=$ 10200). (d): Calcium cell with lytic cytoplasm, ruptured RER and microvilli (X=17000). CD" Cellular debris; Ch: Chromatin materials; DMV: Disrupted microvilli; DOG: Darkly osmiophilic granules; FOG: Faint osmiophilic granules; LC: Lytic cytoplasm; LS: Luminal secretions; LV: Lysosomal vesicles; M: Mitochondria; PN: Pyknotic nucleus; RCM: Ruptured cell membrane; RCJ: Ruptured intercellular junctions; RER: Deformed rough endoplasmic reticulum; V: Vacuoles.

\section{DISCUSSION}

Several toxicological studies have been carried out to evaluate the molluscicidal activities of chemical pesticides, plant extracts and biocides against harmful land snails (Asran, 2001; Gabr et al., 2006; El-Sherbini et al., 2009; Abdel-Haleem, 2013; EL-Sayed et al., 2013 Mwonga et al., 2015; Prabhakaran et al.,
2017). The present study showed that low concentrations of ethanolic Ginger extract caused low mortality percentages after the first day of exposure while the highest mortalities of $M$. cartusiana snails occurred at high concentrations of Ginger at the third and fourth weeks. The presence of alkaloids, flavonoids, tannins, saponins, terpenoids and phenolic derivativescaused the molluscicidal 


\section{Mahmoud Abd El-Atti et al.}

potency of Ginger (Sharma et al., 2016). This finding was in harmony with Singh et al. (2010) who revealed that ceniole, citral, 6 - gingerol and oleoresin extracted from $Z$. officinale rhizomes had potent molluscicidal properties and these active ingredients resulted in an inhibition in the reproductive capacity of Lymnaea acuminate snails. Bakry et al. (2013) showed a rapid decline in survival rate and egg production of Biomphalaria alexandrina snails exposed to Ginger. The obtained results showed that Ginger extract caused disturbancesin the enzymatic activities of treated clover snails. Highly significant elevationsof AST and ALT levelsrecorded after the first day of exposure may be attributed to the activation of defensive mechanisms inside the snail body to overcome the effect of toxicants. The gradual decrease happened in both enzymes later may be duo to cell injuries in digestive gland of treated snail and toxical hepatitis (Farkas et al., 2004). Results demonstrated that Ginger extract caused a significant increase in $\alpha$ - esterase while it caused initial increase in $\beta$-esterase after one day of exposure then gradually decrease till the end of experiment. Increments in the activities of detoxification enzymes ( $\alpha$ and $\beta$-esterases) may result from the stress occurred on enzyme expression system for synthesizing new and higher amounts of detoxification enzymes (Wheeler and Isman, 2000). Thisresultwas in agreement with the findings of El-Gendy (2015) who reported an elevated levelof $\alpha$ - esterase and decreased $\beta$-esterase levels of aphids treated with sublethal concentrations of Origanum vulgare extract. These results disagreed with the findings of Abd-El-Aziz (2014) who proved that the activity of $\alpha$ - esterase enzyme was inhibited while $\beta$-esterase activity was stimulated after treatment with Indoxacarb, Emamectin benzoate and Pyridalyl. Phenoloxidase is an antioxidant enzymeand plays an important role in the immune system of most invertebrates (Smith and Soderhall, 1991; Soderhall and Cerenius, 1998). The activity of Phenol oxidases were stimulated after the entrance of exotoxins inside organisms (Lee et al., 1998). Ginger ethanolic extract caused significant increase in the PO activity for a week then decreased at the second week. This result may attributed to the disturbances occurred in some defensive mechanisms of the snail as a result to the high stress induced by Ginger extract. These results are in conformity with Farrag et al. (2015) who stated that Phenoloxidase levels were significantly increased in treated $5^{\text {th }}$ nymphal instar haemolymph of desert locust after two dayswhile at the fourth days of treatment with Metarhizium anisopliae, their levels were decreased significantly compared to control.

The digestive gland (liver) of molluscs is involved in digestion, absorption beside storage of lipids, glycogen and minerals (Beeby and Richmond, 1988), and plays a major role in detoxication (Henry et al., 1991).The digestive gland of gastropod molluscs is the key organof metabolism serving also as the main site of accumulation and biotransformation of xenobiotics (Desouky, 2006). Histological and ultrastructural investigations on the digestive gland of $M$. cartusiana confirmed the presence of three main cell types; digestive, calcium and excretory cells forming the epithelial wall of digestive tubules. This finding was in harmony with the finding of Heibaet al. (2002); Ismail et al. (2013) and Sharaf et al. (2015) who reported only three cell types. However, Hamed et al. (2007) reported four different cell types.

The present histopathological examinations of the digestive gland treated with $\mathrm{LC}_{25}$ Ginger extract showed tubular deteriorations, tissue exudates, hemocytes infiltration, excessive luminal secretions, 


\section{Control of the glassy clover snails Monacha cartusiana using Zingiber officinale extract as an ecofriendly molluscicide}

cell lysis and some necrotic areas appearinside tubules. Acini of ovotestis were distorted and contained deformed egg and sperms. These findings were in agreement with Abdel-Haleem, (2014) who reported a marked inhibition of the various stages of gametogenesis of terrestrial slugs treated with Origanum syriacum.

Electronmicroscopic examinations showed severely ruptured microvilli, lacerated cell membranes, disorganized RER and condensation of the matrix of mitochondria. These damaged cellular alterations may be due to the direct toxic effect of Ginger extract. Mitochondrial shrinking might be due to toxicant-induced inhibition of $\mathrm{Na}^{+} / \mathrm{H}^{+}$transporter and impairment of the overall osmoregulatory mechanism of the cell (Vilella et al., 1991).In this concern, Hamed et al. (2007)showed disruption and reduction of microvilli, increased number of calcium spherules and presence of large numbers of excretory granules in the excretory cells in the digestive gland of $E$. vermiculataexposed to methomyl. Moreover, Sharaf El-Din et al. (2012) indicated severe ultrastructural alterations in the cerebral ganglia of treated with Biomphalaria alexandrina exposed to ethanolic extract of Anagalis arvensis in the form of, pyknotic nuclei, atrophy of the perikarya of some neurons, fragmentation or dilation of rough endoplasmic reticulum, damage of mitochondria, and vacuolation of cytoplasm. Furthermore, Ustina et al. (2018) investigated ultrastructural alternations in the digestive gland of the Egyptian slug, Limax maximus exposed to thymol pesticide and they reported cytoplasmic vacuolation, degeneration of some nuclei, rupture of microvilli and increasing of calcium spherules inside secretory cells.

\section{Conclusion}

Ginger extract was showed highly toxical degrees against the clover snails $M$. cartusiana and resulted in various biochemical, histopathological and ultrastructural disturbances. Ginger extract caused severe deformations of both eggs and spermsand this may inhibit the flourishing of clover snail's populations at Sharkia Governorate.Therefore, this natural product may be incorporated into apply the control programs of land snailsinstead of using harmful synthetic pesticides. Poisonous baits control technique used in this study is safe for non-target organisms and considered as asubstitutional method in spite of the classical spray control methods.

\section{REFERENCES}

Abdel-Haleem, A.A. (2013). Molluscicidal impacts of some Egyptian plant extracts on protein and DNAcontents of two snail-vectors of schistosomiasis, using electrophoresis. J. Bas. \& Appl. Zool., 66: 34-40.

Abdel-Haleem, A. A. (2014). Cytotoxicity of Egyptian plant extract Origanum syriacum on gametogenesis of two Egyptian terrestrial slugs, using TEM. Int. J. Acad. Sci. Res., 2 (1): 01-08.

Abd-El-Aziz, H. S. (2014). Effect of some insecticides on certain enzymes of Spodoptera littoralis (Bosid.). Egypt. J. Agric. Res., 92 (2):501-512.

Ahmad, F.; Sagheer, M.; Hammad, A.; Rahman, S.M. and Mansoor-UlHasan (2013). Insecticidal activity of some plant extracts against Trogoderma granarium (E.). The agriculturists, 11(1): 103-111.

Amri, A. and Touil-Boukoffa, C. (2016). In vitro anti-hydatic and immunomodulatory effects of ginger and [6]gingerol.Asia. Pac. J. Trop. Med., 9(8): 749-756. 
Mahmoud Abd El-Atti et al.

Asran, F.D. (2001). Evaluation and implementation of novel and environmentally safe approaches in IPM. Program for terrestrial snails. $\mathrm{Ph} . \mathrm{D}$. Thesis, Institute of Environ. Studies and Res. Ain shams Univ. Egypt. Pp.199.

Bakry, F.A.; Abd El-Atti, M.S. and, Ismail, S.M. (2013). Effect of Zingiber officinal (ginger) on, electrophoresis analysis and biochemical aspects of Biomphalaria alexandrina snails infected with Schistosoma mansoni. Int. Scie. Eng. Res., 4(11):11471154.

Beeby, A. and Richmond, L. (1988). Calcium metabolism in two populations of the snail, Helix aspersa on a high lead diet. Arch. Environ. Contam.Toxicol., 17: 501511.

Desouky, M.A. (2006).Tissue distribution and subcellular localization of trace metals in the pond snail Lymnaea stagnalis with special reference to the role of lysosomal granules in metal sequestration. Aquat. Toxicol., 77: $143-152$

Edwin, I.E. and Jacob, I.E. (2017). Bioinsecticidal potency of five plant extracts against Cowpea weevil, Callosobruchus maculatus (F.), on stored Cowpea, Vigna unguiculata (L.). Jord. J. Biol. Sci., 10, (4):317 322.

El-Deeb, H.I., Zedan, H.A.; Abd-All, S.M. and Mohamed, H.L. (1999). Toxicity and biochemical studies on the terrestrial snail Monacha cantiana treated with some natural products and pesticides. 2nd Int. Conf. Pest Control, Mansoura, Egypt. Sept.1999.

El-Gendy, R.M.A. (2015). Application of some recent techniques to control the cabbage aphid, Brevicoryne brassicae (L.) (Homoptera: Aphididae). Ph.D. Thesis. Fac. Sci. Zagazig Univ.Pp205.

El-Okda, M.M.K. (1984). Land Mollusca infestation and chemical control in El-Ismailia Governorate. Agric. Res. Rev., 62(1): 87-92.

EL-Sayed, A. H. (2010): Mollusicidal effects on some chemical compounds against Monacha cartusiana (Müller) and Eobania vermiculata (Müller) land snails under laboratory and field conditions. Egypt. J. Agric. Res., 88(4):1197-1207.

El-Sherbini, G.T.; Zayed, R.A. and ElSherbini, E.T. (2009). Molluscicidal activity of some Solanum species extracts against the snail Biomphalaria alexandrina. J. Parasitol. Res., 2009: 675-680.

Farkas, J.P.; Farkas, P. and Hyde, D. (2004). Liver and gastroenterology tests. In: Basic Skills in Interpreting Laboratory Data, Lee, M. (Ed.). 3rd Edn., American Society of Health System Pharmacists Inc., USA., pp: 330-336.

Farrag, A.A.; Abd- Elfattah, T.A.; Abdelatef, G.M. and El-Dydamony, M. K. (2015). Effect of four bioactive compounds separately and in combination with Metarhizium anisopliae on the activity of some haemolymph enzymes of Schistocerca gregaria (forskal). J. Plant Prot. Path., Mansoura Univ., 6 (6): 871-883.

Gabr, W.M.; Youssef, A.S. and Khidr, F.K. (2006). Molluscicidal effect of certain compounds against two land snail species Monacha obstructa and Eobania vermiculata under laboratory and field conditions. Egyp. J. Agricul. Res.. 84(1):43-50. 


\section{Control of the glassy clover snails Monacha cartusiana using Zingiber officinale extract as an ecofriendly molluscicide}

Godan, D.(1983). Pest slugs and snails, biology and control. Springer-Verlag Berlin, Heidelberg.445 pp.

Goldstein, A. (1964). Biostatistics: An introductory text. Macmillan, New York. 51.

Hamed, S. S.; Abdelmeguied, N. E.; Essawy, A. E.; Radwan, M. A. and Hegazy, A. E.(2007): Histological and ultrastructural changes induced by two carbamate molluscicides on the digestive gland of Eobania vermiculata. J. Biol. Sci. 7(6):10171037.

Heiba, F. N.; Al-Sharkawy, I.M. and AlBatal, A.A. (2002). Effects the insecticide, lannate, on the land snails, Eobania vermiculata and Monacha cantiana, under laboratory conditions. J. Biol. Sci., 2(1):8-13.

Henry, M.; Boucaud-Camou, E. and Lefort, Y.(1991). Functional microanatomy of the digestive gland of the scallop Pecten maximus (L.). Aquat. Liv. Resour., 4: 191-202.

Ishaaya, I.(1971):Observations on the phenoloxidase system in the armored scales Aonidiella aurantii and Chrysomphalus aonidum. Omp. Bioch. Phys., 39: 935-943.

Ismail, S.H.; Rashed, A.A.; Abou-senna, F.M. and Abed, M. (2013). Physiological and histochemical studies on the land snail, Monacha cartusiana in Sharkia Governorate. Egypt. J. Agric. Res., 91 (1):207216.

Pieńkowska, J.R. (2018). Distribution of Monacha claustralis (Rossmässler, 1834) and $M$. cartusiana (O. F. Müller, 1774) (Eupulmonata: Hygromiidae) in central European and Balkan countries: new data. Folia Malacologica, 26: 103-120.
Pieńkowska, J.R.; Manganelli, G.; Giusti, F.; Barbato, D.; Hallgass, A. and Lesicki, A. (2019). Exploration of phylogeography of Monacha cantianas. 1. continues: the populations of the Apuan Alps (NW Tuscany, Italy) (Eupulmonata, Stylommatophora, Hygromiidae). ZooKeys, 814: 115-149.

Lee, S. Y.; Cho, M. Y.; Hyun, J. H; Lee, K. M. and Homma, K. I. (1998). Molecular cloning of cDNA for prophenol-oxidase-activating factor I, a serine protease is induced by lipopolysaccharide or1,3-beta-glucan in coleopteran insect, Holotrichia diomphalia larvae. Europ. J. Biochem., 257: 615-621.

Lokma, M.H. (2013). Studies on some terrestrial molluses injurious to vegetables and field crops in East Delta locality (Sharkia and Ismailia). Ph.D., Fac. Agric., Moshtohor. Benha Univ. pp174.

Mwonga, K.B.; Waniki, N.E.N.M.; Dorcas, Y.S. and Piero, N.M. (2015). Molluscicidal effects of aqueous extracts of selected medicinal plants from Makueni County, Kenya. Pharm. Anal. Acta., 6:11..

Prabhakaran, G.; Bhore, S. J. and Ravichandran, M. (2017).Development and evaluation of poly herbal molluscicidal extracts for control of apple snail (Pomacea maculata).Agriculture 7, 22.1-11.

Massoud, A. M. and Habib, F. S. M. (2003). The effect of Myrrh Commiphora molmol on the infected snails of Schistosma species and their egg masses: Effect on shedding of cercariae and on snail fecundity. J. Egypt. Soc. Parasitol., 33(2):585596. 
Mahmoud Abd El-Atti et al.

Nikoli, M.; Vasi, S.; Jelena, D.; Stefanovi, O. and Ljiljana, C.(2014). Antibacterial and anti-biofilm activity of ginger (Zingiber officinale (roscoe)) ethanolic extract. Krag. J. Sci., 36: 129-136.

Reitman, S. M. and Frankel, S. (1957): Acolorimetric method for determination of serum glutamic pyruvic transaminase. Am. J. Clin. Path., 28: 56-63.

Sharaf, H.M.; Salama, M.A. and Abd ElAtti, M.S. (2015). Biochemical and histological alterations in the digestive gland of the land snail Helicella vestalis (locard, 1882) exposed to methiocarb and chlorpyrifos in the laboratory. Int. J. Sci. and Res., 4(7): 334-343.

Sharaf El-Din, T.A.; El-Sayed, K.A.; Abdel Hamid, H. and Mahmoud, M.B. (2012). Mode of action of some molluscicides on neurons of Biomphalaria alexandrina snail. Middle-East J. Sci. Res., 12(10):1413-1419.

Sharma, N.; Tiwari, R. and Srivastava, M. P., (2013). Zingiber officinale (Roscoe). Oil: A preservative of stored commodities against storage mycoflora. Int. J. Curr. Microbiol. App. Sci., 2(7): 123-134.

Sharma, P. K.; Singh, V.; Ali, M. and Kumar, S. (2016). Effect of ethanolic extract of Zingiber officinale (Roscoe) on the central nervous activity in mice. Ind. J. Exper. Biol., 54: 664-669.

Singh, S.K.; Yadav, R.P. and Singh, A. (2000). Molluscicidal activity of Thevetia peruvianaa common medicinal plant ofIndia. J. Medic. and Arom. Plant Sci., 22(4A)23(1A), 113-116.
Singh, S.K. and Singh, A. (2010). Metabolic changes in freshwater harmful snail Lymnaea acuminate due to aqueous extract of bark and leaf of Euphorbia pulcheima plant. American-Eurasian J. Toxi. Sci.m 2(1): 13-19.

Smith, V. J. and Soderhall, K. (1991): Comparison of phenoloxidase activity in the blood of marine invertebrates. Dev. Comp. Immunol. 15(4): 251-261.

Soderhall, K. and Cerenius, L. (1998). Role of pro-phenoloxidase activating system in invertebrate immunity. Curr. Opin. Immunol., 10(1):23-28.

Ustina N.T.H.; Abdel-Haleem, A.A.; Omaima M.M. and Eman H.I. (2018). Histological and ultrastructural alternations in the digestive gland of the Egyptian slug, Limax maximus (Linnaeus, 1758) treated with botanic molluscicidal thymol, with reference to biological studies. Egypt. J. Aqu. Biol. Fish.. 22(5): 137- 148.

Van Asperen, K. (1962). A study of housefly esterase by means of sensitive colorimetric method. J. Insect Physiol., 8: 401- 416.

Vilella, S ; Zonno, V; Cassano, G ; Maffia, M. and Storelli, C. (1991). $\mathrm{Na}^{+} / \mathrm{H}^{+}$ exchange in the kidney of eels Anguilla anguilla adapted to sea water or to freshwater environments, studies with brush border membrane vesicles. Comp. Biochem. Physiol.,102: 445-560.

Wheeler, D.A. and M.B. Isman (2000). Effect of Trichilia americana extract on feeding behavior of Asian armyworm, Spodoptera littoralis. J. Chem. Ecol. , 26:2791-2800. 
Control of the glassy clover snails Monacha cartusiana using Zingiber officinale extract as an ecofriendly molluscicide

مكافحه قواقع البرسيم الزجاجي موناكا كارتوزيانا بإستخدام مستخلص الزنجبيل كمبيد رخوي صديق للبيئه

$$
\begin{aligned}
& \text { محمود عبد العاطي1 ، علي الثيخ2، عبد المنعم خليل1، وسام الجوهري2 }
\end{aligned}
$$

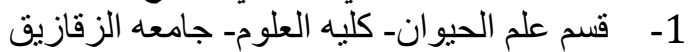

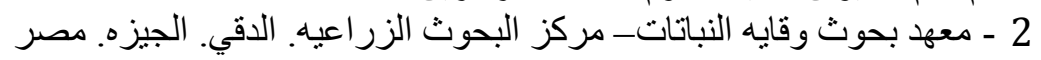

$$
\begin{aligned}
& \text { المستخلص }
\end{aligned}
$$

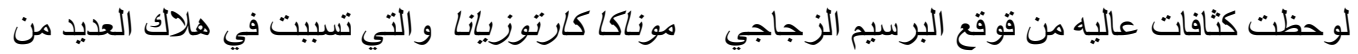

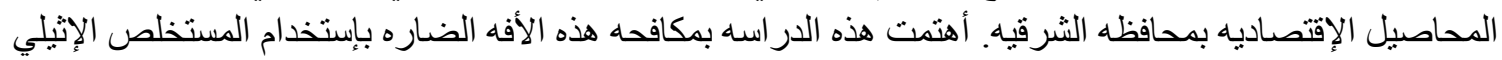

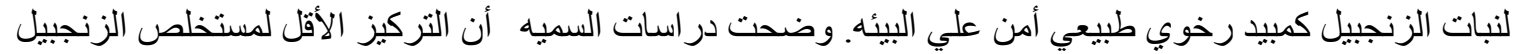

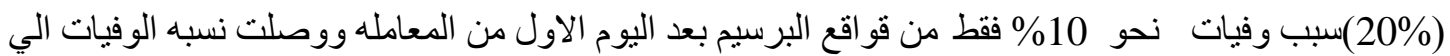

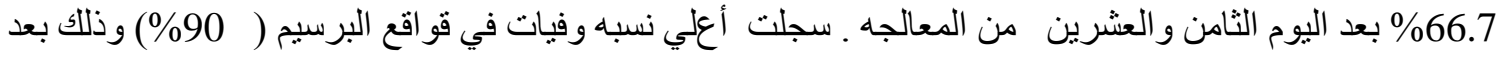

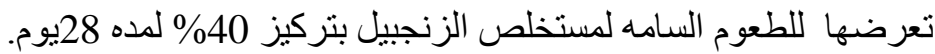

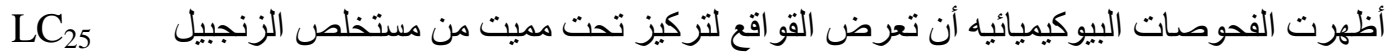

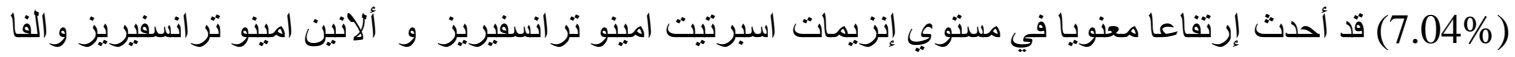

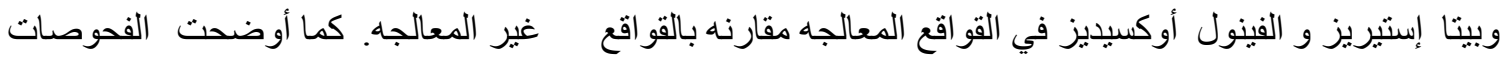

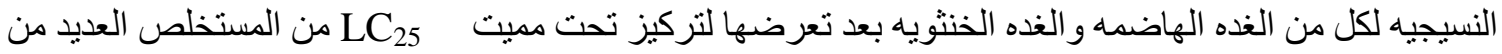

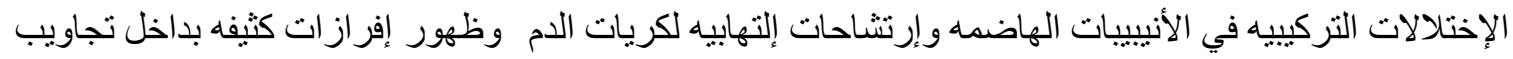

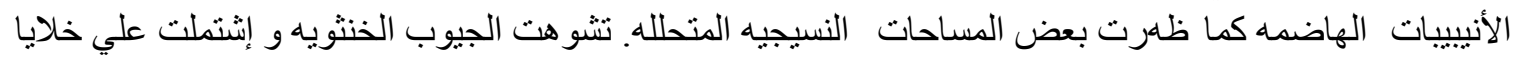

$$
\begin{aligned}
& \text { بيضيه غير طبيعيه وحيو انات منويه مشو هه. }
\end{aligned}
$$

